Original article

\title{
The influence of estradiol and progesterone on the concentrations of uterine oxytocin receptors and plasma PGFM in response to oxytocin in ovariectomized gilts
}

\author{
Anita FrANCZAK ${ }^{\mathrm{a}}$, Jaroslaw STASZKIEWICZ ${ }^{\mathrm{a}}$, Marek KOZIOROWSKI ${ }^{\mathrm{b}}$, \\ Genowefa KotwicA ${ }^{\text {a* }}$ \\ a Department of Animal Physiology, University of Warmia and Mazury, Olsztyn, \\ Oczapowski St. 5, 10-178 Olsztyn, Poland \\ ${ }^{\mathrm{b}}$ Department of Animal Physiology and Reproduction, University of Rzeszów, Rzeszów, Poland
}

(Received 11 March 2002; accepted 24 June 2002)

\begin{abstract}
Peripubertal gilts $(n=25)$ were treated with corn oil $(\mathrm{CO})$ or ovarian steroids, one month following an ovariectomy. The first day of treatment was assigned as the first day of the experiment. The gilts received: Group $(\mathrm{Gr}) \mathrm{I}(n=4)-\mathrm{CO}\left(2 \mathrm{~mL} \cdot \mathrm{day}^{-1}\right.$ from 1 st to 12 th day $)$, Gr II $(n=4)$ and $\mathrm{Gr}$ III $(n=4)$ - progesterone $\left(\mathrm{P}_{4} ; 10\right.$ to $100 \mathrm{mg}^{-}$day $^{-1}$ from 1 st to 12 th day), $\mathrm{Gr} \operatorname{IV}(n=5)$ - estradiol benzoate (EB; $400 \mu \mathrm{g} \cdot \mathrm{day}^{-1}$ from 1 st to 3rd day), Gr V $(n=4)$ and Gr VI $(n=4)-\mathrm{EB}+$ $\mathrm{P}_{4}$ (EB $400 \mu \mathrm{g} \cdot \mathrm{day}^{-1}$ from $1 \mathrm{st}$ to $3 \mathrm{rd}$ day, $20 \mu \mathrm{g} \cdot \mathrm{day}^{-1}$ at 6 th and 9 th day, $50 \mu \mathrm{g}$ at 12 th day plus $\mathrm{P}_{4} 10$ to $100 \mathrm{mg}$ from 4 th to 15 th day). All gilts were injected with oxytocin (OT; $20 \mathrm{IU}$; i.v.) on the following days of the experiment: 13th (Gr I and Gr II), 15th (Gr III and Gr IV), 16th (Gr V) and 18th (Gr VI). Concentrations of the $\mathrm{PGF}_{2 \alpha}$ metabolite - PGFM were determined in blood samples, collected from $30 \mathrm{~min}$ before to $120 \mathrm{~min}$ after OT injection. Baseline PGFM concentrations (30 min before OT) differed among treatment groups and were the highest in $\mathrm{Gr} \mathrm{V}$ and $\mathrm{Gr} \mathrm{VI}(P<0.01$ vs. other groups). The magnitude of the PGFM response to OT increased only in four of the five gilts of Gr IV and in three of the four gilts of Gr VI, and it was higher $(P=0.009)$ in Gr VI than in Gr IV. In the remaining groups, PGFM concentrations did not increase above the baseline in response to OT. The day after OT injection, oxytocin receptors (OTR) were found in the uterine tissues of all animals studied. The lowest OTR concentrations were in Gr I $-75.5 \pm 11.2 \mathrm{fmol} \cdot \mathrm{mg}$ protein ${ }^{-1}$ and the highest in $\mathrm{Gr} \mathrm{IV}-$ $712.9 \pm 86.7 \mathrm{fmol} \cdot \mathrm{mg}$ protein ${ }^{-1} ;(P<0.05$ vs. other groups $)$. The values of $\mathrm{K}_{\mathrm{d}}$ of OTR differed among groups $(P<0.001)$ and ranged from $1.62 \pm 0.44 \mathrm{nM}$ in $\mathrm{Gr}$ I to $12.08 \pm 1.9 \mathrm{nM}$ in Gr VI. A positive correlation $(r=0.54 ; P<0.01)$ between plasma $\mathrm{E}_{2}$ and uterine OTR concentrations was observed. In conclusion, $\mathrm{E}_{2}$ and $\mathrm{P}_{4}$ are involved in both $\mathrm{PGF}_{2}$ synthesis/secretion and OTR formation, however, full $\mathrm{PGF}_{2 \alpha}$ response to OT does not develop before puberty. Estrogens are evident stimulators of uterine OTR synthesis in gilts.
\end{abstract}

prostaglandin $F_{2 \alpha}$ secretion / oxytocin receptors / gilts

* Correspondence and reprints

E-mail: gkotwica@uwm.edu.pl 


\section{INTRODUCTION}

Oxytocin binding with its own uterine receptor is involved in the regulation of $\mathrm{PGF}_{2 \alpha}$ secretion in pigs $[50,51]$ and ruminants [12, 31]. Concentrations of specific OTR in the endometrium and $\mathrm{PGF}_{2}$ respond to OT challenge change during the course of the oestrous cycle in gilts $[10,20$, $33,51]$, ewes [43, 48] and cows [13, 31]. Generally, the highest OTR concentrations are observed during oestrus and the lowest in the mid-luteal phase. Elevation in both mRNA OTR and OTR concentrations in the luminal epithelium of the endometrium is observed around luteolysis in the ewes [37, $41,44]$. However, in pigs, luteolysis is not preceded by a temporal increase in endometrial OTR $[29,33]$. In sows, the concentration of plasma $\mathrm{PGF}_{2 \alpha}$ metabolite (PGFM) significantly increased in response to the OT administered around luteolysis (days 14-16), but there is no response during the early luteal phase (days 4-6) and a weak response is found in the mid-luteal phase (days 9-12) of the oestrous cycle [6, 20]. These data indirectly suggest that cyclic changes of estrogens $\left(E_{2}\right)$ and the $\mathrm{P}_{4}$ level during the oestrous cycle may influence uterine OTR concentration and $\mathrm{PGF}_{2 \alpha}$ response to OT. The results of an in vitro study on luminal epithelial cells of pregnant ovine endometrium showed that the expression of the OTR gene was stimulated by $\mathrm{E}_{2}$ and inhibited by $\mathrm{P}_{4}$ [28].

Functional OTR were measured in endometrial cells of ovariectomized (OVX) ewes and cows treated with $\mathrm{E}_{2}$ and $\mathrm{P}_{4}[3,24$, $27,41]$. The regulatory effect of steroids on OTR concentration is dependent on the following: (1) the duration of the exposure of uterine cells to $\mathrm{E}_{2}$ and $\mathrm{P}_{4}$; (2) the availability of respective steroid receptors in these cells; (3) the ratio of plasma concentrations of $E_{2}$ and $\mathrm{P}_{4}$ and; (4) the sequence of hormone action on target uterine cells [49]. Ovarian steroids are also necessary for the biosyn- thesis of $\mathrm{PGF}_{2 \alpha}$ in endometrial cells [7, 8]. Estrogens and $\mathrm{P}_{4}$ are involved in the accumulation of lipid droplets and the accessibility of arachidonic acid in endometrial cells [38]. Estrogens affect the activity of the cyclooxygenase pathway [7] whereas $\mathrm{P}_{4}$ affects prostaglandin synthase [8]. Edgerton et al. [11] showed that OVX sows must receive both $\mathrm{E}_{2}$ and $\mathrm{P}_{4}$ replacement for the secretion of $\mathrm{PGF}_{2 \alpha}$ in response to OT. However their study did not explain the role of $\mathrm{E}_{2}$ and $\mathrm{P}_{4}$ in uterine OTR formation in sows. Based on the results of the experiments in ewes [3, 41, 47] and cows [24] and presumably also in sows, $\mathrm{E}_{2}$ and $\mathrm{P}_{4}$ are involved in this process. Therefore, in this study the peripubertal gilts were ovariectomized and treated with $\mathrm{EB}$ and $\mathrm{P}_{4}$ to determine the role of $\mathrm{E}_{2}$ and $\mathrm{P}_{4}$ in both $\mathrm{PGF}_{2 \alpha}$ secretion in response to OT and in uterine OTR production.

\section{MATERIALS AND METHODS}

\subsection{Animals and experimental design}

Peripubertal gilts $(n=25)$ were used in this study. One month after ovariectomy, a polyvinyl chloride catheter was inserted into the jugular vein [23] of seven to eight month-old gilts (mean body weight $100 \pm$ $9 \mathrm{~kg}$ ). The gilts were divided into six groups and received as follows: $\mathrm{Gr} \mathrm{I}(n=4)-\mathrm{CO}$ ( $2 \mathrm{~mL} \cdot$ day $^{-1}$ from the 1 st to 12 th day), Gr II $(n=4)$ and Gr III $(n=4)-\mathrm{P}_{4}(10$ to $100 \mathrm{mg} \cdot \mathrm{day}^{-1}$ from the $1 \mathrm{st}$ to 12 th day), Gr IV $(n=5)-$ EB $\left(400 \mu \mathrm{g} \cdot\right.$ day $^{-1}$ from the 1 st to 3rd day), Gr V $(n=4)$ and Gr VI $(n=4)-\mathrm{EB}+\mathrm{P}_{4}\left(\mathrm{~EB} ; 400 \mu \mathrm{g} \cdot \mathrm{day}^{-1}\right.$ from the 1 st to $3 \mathrm{rd}$ day, $20 \mu \mathrm{g} \cdot \mathrm{day}^{-1}$ at the 6 th and 9 th day and $50 \mu \mathrm{g}$ at the 12 th day plus $\mathrm{P}_{4} 10$ to $100 \mathrm{mg} \cdot \mathrm{day}^{-1}$ from the 4 th to 15 th day). The first day of injection was assigned as the first day of the experiment. Half of the daily dose of injected substances was given at 8.00 a.m. and the other half at 
8.00 p.m. Doses and the schedule of EB and $\mathrm{P}_{4}$ injection were chosen for the assurance of plasma $\mathrm{E}_{2}$ and $\mathrm{P}_{4}$ concentrations typical for the oestrous cycle in gilts $[15,52]$. The detailed schedule of treatment is given in Table I. All studied gilts received OT (20 IU; i.v.; Intervet, Holand; Tab. I): on day 13 (Gr I and Gr II), day 15 (Gr III and Gr IV), day 16 (Gr V) and day 18 (Gr VI). Blood samples were collected for the analysis of plasma PGFM concentrations. The next day following OT administration, the gilts were slaughtered and fragments of the uterine wall were collected for the determination of OTR concentrations (Tab. I).

\subsection{Blood samples and uterine tissue collection}

Before the morning injection of $\mathrm{CO}$ or hormones, blood samples were collected once daily for determining $\mathrm{E}_{2}$ and $\mathrm{P}_{4}$ plasma concentrations. On the day of OT administration, gilts were bled every $10 \mathrm{~min}$ for 0.5 hour before and every 5 to $10 \mathrm{~min}$ for two hours after OT injection, for plasma PGFM and OT analysis.

Because the endometrium was not fully developed, especially in gilts of Gr I and $\mathrm{Gr} I V$, the fragments of the middle part of the uterine wall $(5 \mathrm{~g})$ were isolated from all studied gilts immediately after they were slaughtered. These tissues were frozen in liquid nitrogen and stored at $-70{ }^{\circ} \mathrm{C}$ until OTR concentrations could be analysed.

\subsection{Plasma hormone determination}

Plasma hormones were determined by RIA according to: Homanics and Silvia [18] for PGFM, Ottobre et al. [35] for $\mathrm{P}_{4}$, Hotchkiss et al. [19] for $E_{2}$ and Schams and Prokopp [40] for OT. The specificity of the antibodies and assay validation of these hormones were described earlier [9, 21, 22, 45]. Intra- and inter-assay coefficients of variations in these studies were: PGFM $-3.8 \%$ and $4.7 \% ; \mathrm{P}_{4}-3.8 \%$ and $5.3 \% ; \mathrm{E}_{2}-3.4 \%$ and $4.1 \%$; OT $-4.3 \%$ and $4.7 \%$.

\subsection{Determination of OTR concentration}

Concentrations of OTR were determined according to Mirando et al. [32] and Whiteaker et al. [50]. The tissue was homogenised and then centrifuged at $80000 \times g$ for $90 \mathrm{~min}$ in $4{ }^{\circ} \mathrm{C}$. For the Scatchard curve construction, $\left[{ }^{3} \mathrm{H}\right] \mathrm{OT}$ (spec. activity $9.25 \mathrm{MBq} \cdot \mathrm{mmol}^{-1}$; NEN Boston, USA) at concentrations of $0.125,0.25,0.5,1$ and 2 pmol and 400 pmol OT were used. The protein level was analysed according to the Bradford method [39]. The specificity of $\left[{ }^{3} \mathrm{H}\right] \mathrm{OT}$ binding was indicated by displacement with related peptides, which was $96.23 \%$ for OT, $99.33 \%$ for $\left(\mathrm{Tyr}^{4}, \mathrm{Gln}^{7}\right)$ - OT - and $41 \%$ for lisynevasopressin.

\subsection{Statistical analysis}

For verification of the accuracy of EB and $\mathrm{P}_{4}$ doses, the mean plasma concentrations of $E_{2}$ and $P_{4}$ were calculated for each day on which these hormones were injected. The mean ( \pm SEM) plasma levels of $\mathrm{P}_{4}, \mathrm{E}_{2}$ and OT were also calculated on the days when OT was injected.

The baseline of PGFM was calculated for each gilt, as the mean of the concentrations from 30 to 0 min before OT injection. The magnitude of the PGFM response was defined as the maximum concentration of this metabolite, above the baseline, during the $30 \mathrm{~min}$ ( 0 to $30 \mathrm{~min}$ ) after OT injection. These values were calculated for each gilt, but statistical analyses (by the Student $T$-test; Microsoft Excel 5.0/7.0) were done in four of the five gilts of Gr IV and in three of the four gilts of Gr VI. In the other groups studied, plasma PGFM levels increased in response to OT only in individual females. Plasma $\mathrm{E}_{2}, \mathrm{P}_{4}$, OT and baseline PGFM levels on the day of OT injection were 


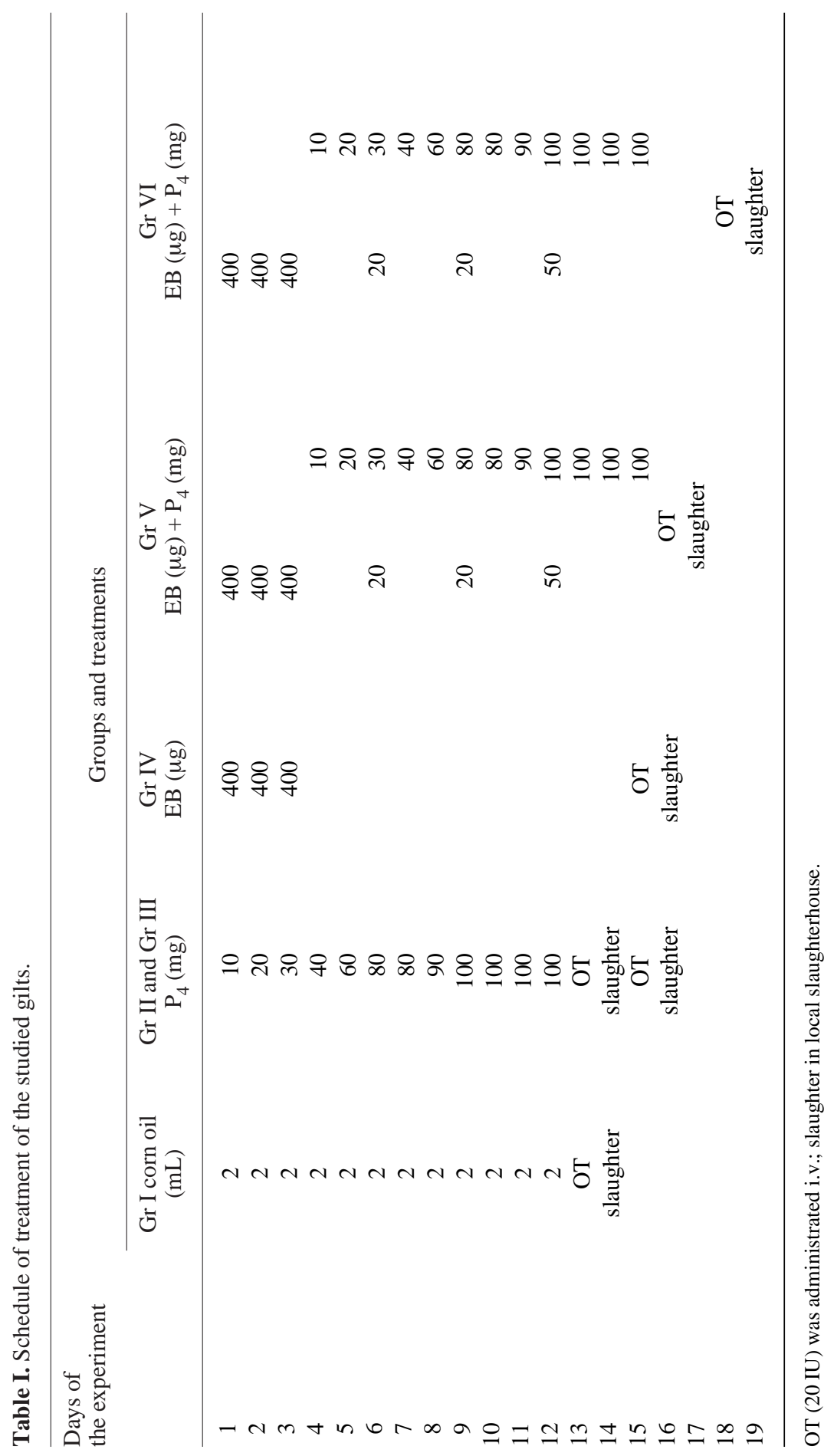


compared between the groups with ANOVA using the GLM procedure of the Statistical Analysis System (SAS). ANOVA was also used for determining differences among the studied groups for OTR concentrations and their $\mathrm{K}_{\mathrm{d}}$ (dissociation constants).

\section{RESULTS}

\subsection{Plasma concentrations of $\mathbf{P}_{4}$, $\mathrm{E}_{2}$ and $\mathrm{OT}$ after administration of these hormones}

Plasma $\mathrm{P}_{4}$ concentrations in $\mathrm{Gr} \mathrm{I}(\mathrm{CO})$ and in Gr IV $(\mathrm{EB})$ were low (mean \pm SEM $-0.4 \pm 0.09 \mathrm{ng} \cdot \mathrm{mL}^{-1}$ ) during all days of the experiment. In gilts receiving $\mathrm{P}_{4}$ and $\mathrm{EB}+$ $\mathrm{P}_{4}$ plasma $\mathrm{P}_{4}$ increased gradually and the hormone concentrations plateaued on days 7 to 14 (Gr II and Gr III; $24.4 \pm$ $\left.1.3 \mathrm{ng} \cdot \mathrm{mL}^{-1}\right)$ and 9 to $17(\mathrm{Gr} \mathrm{V}$ and Gr VI; $\left.27.3 \pm 1.7 \mathrm{ng} \cdot \mathrm{mL}^{-1}\right)$. On the days of OT injections, plasma $\mathrm{P}_{4}$ levels differed $(P<0.01)$ between the groups: II and III as well as V and VI, depending on the time from the last $\mathrm{P}_{4}$ injection (Tab. II, Fig. 1).

Mean plasma $\mathrm{E}_{2}$ concentrations in gilts treated with corn oil (Gr I) or $\mathrm{P}_{4}$ (Gr II and $\mathrm{Gr}$ III) were at the same level (25.98 \pm $1.61 \mathrm{pg} \cdot \mathrm{mL}^{-1}$ ) during the whole experiment. The treatment of OVX gilts with EB or EB
$+\mathrm{P}_{4}$ produced high plasma $\mathrm{E}_{2}$ concentrations and it ranged from $31.4 \pm 1.6 \mathrm{pg} \cdot \mathrm{mL}^{-1}$ to $260.3 \pm 1.6 \mathrm{pg} \cdot \mathrm{mL}^{-1}$ (Gr IV) and from $27.7 \pm 1.6 \mathrm{pg} \cdot \mathrm{mL}^{-1}$ to $156.2 \pm 39.9 \mathrm{pg} \cdot \mathrm{mL}^{-1}$ ( $\mathrm{Gr} \mathrm{V}$ and $\mathrm{Gr} \mathrm{VI})$. In these groups plasma $\mathrm{E}_{2}$ concentrations were above $30 \mathrm{pg} \cdot \mathrm{mL}^{-1}$ from the second to the last day of the experiment (Tab. II, Fig 1).

Oxytocin administration (20 IU; i.v.) caused an elevation of its plasma concentrations from $19.0 \pm 1.9 \mathrm{pg} \cdot \mathrm{mL}^{-1}$ before injection to $319.1 \pm 45.3 \mathrm{pg} \cdot \mathrm{mL}^{-1} 5 \mathrm{~min}$ after injection. Oxytocin plasma level was high $\left(73.2 \pm 6.2 \mathrm{pg} \cdot \mathrm{mL}^{-1}\right)$ during one hour after OT treatment and this did not differ $(P>0.05)$ among the groups studied.

\subsection{The influence of steroid treatments and OT administration on plasma PGFM concentrations}

The mean $( \pm$ SEM) concentrations of PGFM on the days of OT injections (period from -30 to $+120 \mathrm{~min}$ ) are presented in Figure 1. On these days, baseline PGFM concentrations (period from -30 to $0 \mathrm{~min}$ ) differed between the groups (Tab. II) and were the highest in the gilts receiving both steroids - Gr V and Gr VI $(P<0.01$ vs. other groups). In the gilts treated with $\mathrm{P}_{4}$ (Gr II and Gr III) or $\mathrm{EB}+\mathrm{P}_{4}(\mathrm{Gr} \mathrm{V}$ and

Table II. Mean ( \pm SEM) plasma concentrations of $\mathrm{P}_{4}, \mathrm{E}_{2}$ (period from -30 to $+120 \mathrm{~min}$ ) and PGFM (period from -30 to $0 \mathrm{~min}$; baseline) in studied gilts on the days of experiment in which OT (20 IU) was administered.

\begin{tabular}{lcccc}
\hline Groups & $\begin{array}{c}\text { Day of OT } \\
\text { injection }\end{array}$ & $\mathrm{P}_{4}\left(\mathrm{ng} \cdot \mathrm{mL}^{-1}\right)$ & $\mathrm{E}_{2}\left(\mathrm{pg} \cdot \mathrm{mL}^{-1}\right)$ & $\mathrm{PGFM}\left(\mathrm{pg} \cdot \mathrm{mL}^{-1}\right)$ \\
\hline I (corn oil) & 13 & $0.4 \pm 0.08^{\mathrm{a}}$ & $20.2 \pm 3.1^{\mathrm{a}}$ & $69.1 \pm 4,9^{\mathrm{a}, \mathrm{b}}$ \\
II $\left(\mathrm{P}_{4}\right)$ & 13 & $26.7 \pm 2.1^{\mathrm{c}}$ & $23.6 \pm 1.3^{\mathrm{a}}$ & $60.5 \pm 5,8^{\mathrm{b}}$ \\
III $\left(\mathrm{P}_{4}\right)$ & 15 & $8.6 \pm 1.1^{\mathrm{b}}$ & $29.1 \pm 3.9^{\mathrm{a}}$ & $101.8 \pm 7.1^{\mathrm{c}}$ \\
IV $(\mathrm{EB})$ & 15 & $0.4 \pm 0.1^{\mathrm{a}}$ & $60.9 \pm 9.2^{\mathrm{b}}$ & $82.6 \pm 8.1^{\mathrm{a}, \mathrm{c}}$ \\
V $\left(\mathrm{EB}+\mathrm{P}_{4}\right)$ & 16 & $29.8 \pm 2.7^{\mathrm{c}}$ & $93.6 \pm 20.6^{\mathrm{c}}$ & $128.6 \pm 8.9^{\mathrm{d}}$ \\
VI $\left(\mathrm{EB}+\mathrm{P}_{4}\right)$ & 18 & $7.5 \pm 0.5^{\mathrm{b}}$ & $37.3 \pm 3.4^{\mathrm{a}, \mathrm{b}}$ & $258.6 \pm 23.4^{\mathrm{e}}$ \\
\hline
\end{tabular}

a, b, c, d, e Means within column with different superscripts differ $(P<0.01)$. 


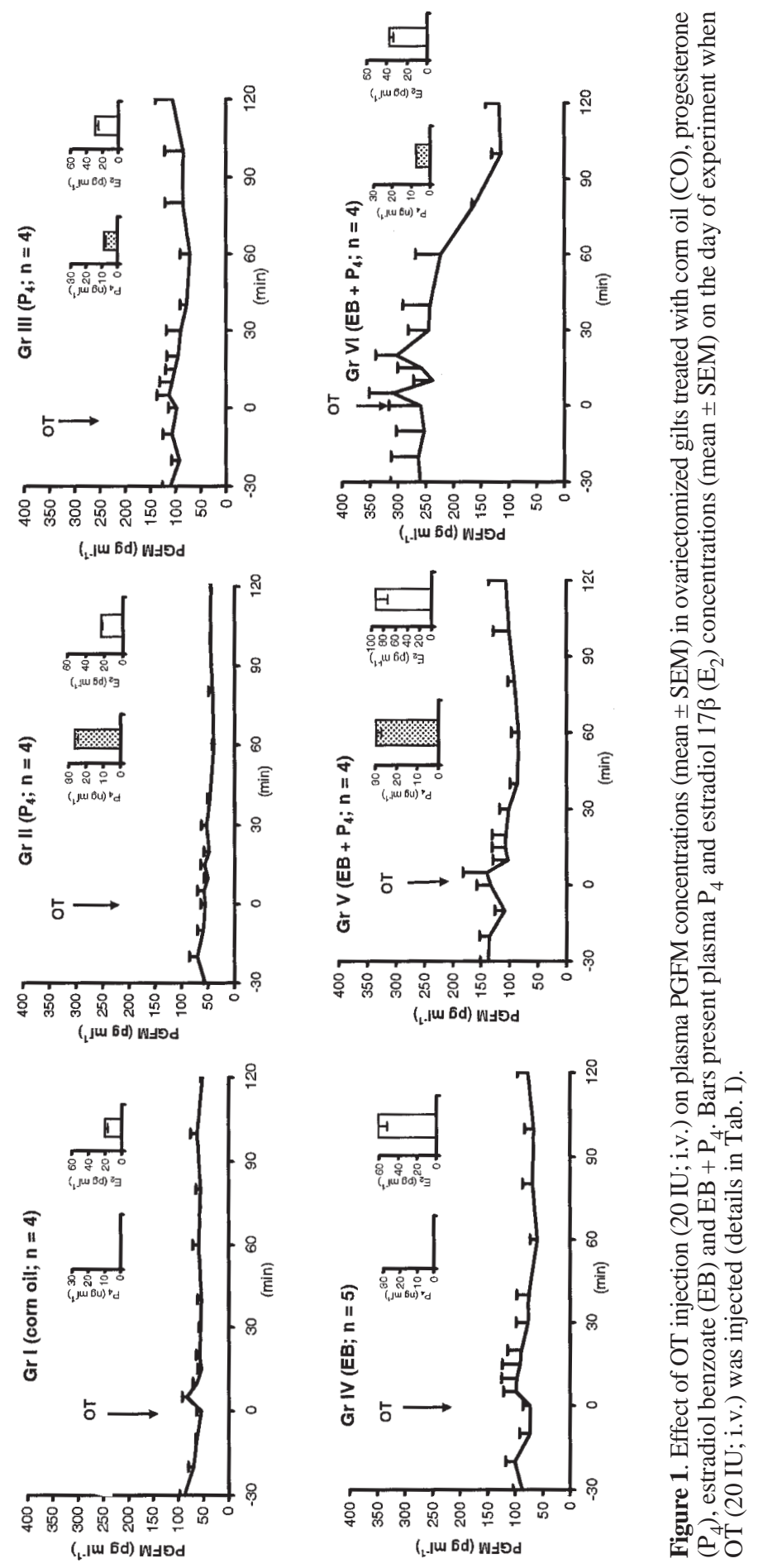


Gr VI), basic PGFM levels were higher $(P<0.01)$ in Gr III vs. Gr II and in Gr VI vs. $\mathrm{Gr}$ V. Baseline concentrations of PGFM were correlated with $\mathrm{E}_{2}(r=0.48 ; P<0.01)$ in all groups and with $\mathrm{P}_{4}(r=-0.289$; $P=0.01)$ in groups II, III, IV and V.

An increase of plasma PGFM concentrations after OT injection were noticed in four of the five gilts of Gr IV (EB) and in three of the four gilts of Gr VI $\left(\mathrm{EB}+\mathrm{P}_{4}\right)$. The magnitude of the PGFM response to OT was higher in gilts of Gr VI $-64.5 \pm$ $10.4 \mathrm{pg} \cdot \mathrm{mL}^{-1}$ than in gilts of Gr IV $-28.5 \pm$ $4.2 \mathrm{pg} \cdot \mathrm{mL}^{-1} ;(P=0.009)$. The responses in the other groups were not significant.

\subsection{Concentrations of OTR in uterine tissues}

The mean $( \pm$ SEM) uterine OTR concentrations are shown in Figure 2. Oxytocin receptors were present in the uterus of all studied gilts. In Gr I (CO) OTR concentration was the lowest $(75.33 \pm 11.2 \mathrm{fmol} \cdot \mathrm{mg}$ protein $^{-1} ; P<0.05$ vs. other groups). The administration of $\mathrm{P}_{4}$ (Gr II and Gr III) or EB (Gr IV) alone increased OTR concentrations by about three-fold (mean \pm SEM $\left.270.1 \pm 31.7 \mathrm{fmol} \cdot \mathrm{mg} \mathrm{protein}^{-1}\right)$ and tenfold $\left(712.86 \pm 86.74 \mathrm{fmol} \cdot \mathrm{mg}\right.$ protein $^{-1}$;
$P<0.05$ vs. other Groups), respectively. In gilts treated with $\mathrm{EB}+\mathrm{P}_{4}(\mathrm{Gr}$ V and Gr VI) the mean OTR concentration was $234.1 \pm 29.1 \mathrm{fmol} \cdot \mathrm{mg}$ protein $^{-1}$. Uterine OTR concentration was positively correlated $(r=0.54 ; P<0.01)$ with plasma $\mathrm{E}_{2}$ level but was not correlated with the $\mathrm{P}_{4}$ level ( $r=-0.08 ; P<0.7)$.

The mean value of $K_{d}$ of OTR for all groups studied was $6.15 \pm 1.92 \mathrm{nM}$ and it ranged from $1.62 \pm 0.44 \mathrm{nM}(\mathrm{Gr} \mathrm{I})$ to $12.08 \pm 1.9 \mathrm{nM}(\mathrm{Gr} \mathrm{VI})$. The value of $\mathrm{Kd}$ of OTR did not differ $(P>0.05)$ in Gr II vs. Gr III (mean \pm SEM $-3.92 \pm 0.53 \mathrm{nM})$ and in Gr V vs. Gr VI (mean \pm SEM $-11.4 \pm$ $2.13 \mathrm{nM})$. The significant differences of $\mathrm{Kd}$ were in Gr I vs. values in Gr IV (5.51 \pm $1.15 \mathrm{nM} ; P<0.05)$, Gr $\mathrm{V}$ and Gr VI $(P<0.001)$ and in Gr II and Gr III vs. values in Gr V and Gr VI $(P<0.001)$.

Plasma PGFM concentration after OT administration was not highly correlated $(r=0.1 ; P>0.6)$ with the concentrations of uterine OTR.

\section{DISCUSSION}

The doses and frequency of $\mathrm{P}_{4}$ administration in the studied gilts resulted in typical profiles and concentrations of plasma $\mathrm{P}_{4}$ for

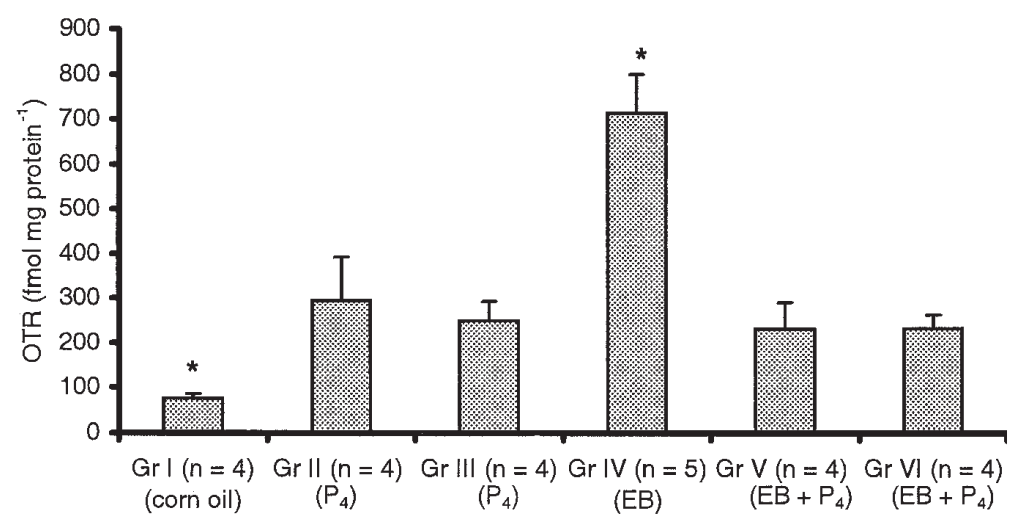

Figure 2. Mean $( \pm$ SEM) concentrations of uterine oxytocin receptors in ovariectommized gilts treated with corn oil, progesterone $\left(\mathrm{P}_{4}\right)$, estradiol benzoate $(\mathrm{EB})$ and $\mathrm{EB}+\mathrm{P}_{4}$ (details in Tab. I). 
the luteal phase of the oestrous cycle [52]. However, injections of EB increased plasma $\mathrm{E}_{2}$ concentrations considerably above the physiological level [5].

Baseline concentrations of PGFM were higher in the gilts treated with $\mathrm{EB}+\mathrm{P}_{4}(\mathrm{Gr} \mathrm{V}$ and $\mathrm{Gr} \mathrm{VI}$ ), compared to the other groups. Thus the results of this study confirmed the interaction of $\mathrm{E}_{2}$ and $\mathrm{P}_{4}$ for $\mathrm{PGF}_{2 \alpha}$ synthesis in the uterus $[8,38]$. Simultaneously, it was shown that during $\mathrm{P}_{4}$ dominance $\mathrm{PGF}_{20}$ secretion had been suppressed. In gilts with higher plasma $\mathrm{P}_{4}$ levels, baseline PGFM concentrations remained lower (results of Gr II vs. Gr III and Gr V vs. Gr VI). In cyclic gilts basic and OT-stimulated plasma PGFM concentrations were higher on days 14-16 of the oestrous cycle, i.e. on days when plasma $\mathrm{P}_{4}$ started to decline [20, 36].

After a few days of activity of ovarian steroids in OVX gilts, OT administration had a weak influence on $\mathrm{PGF}_{2 \alpha}$ secretion. The magnitude of the PGFM response above the baseline increased only in seven of the twenty-five studied gilts. The ineffectiveness of OT treatment was not due to the dose of the peptide used since the injection of 20 IU OT resulted in its plasma level being comparable to the values measured in sows during parturition [16], mating [22] or suckling [34]. Moreover, in our earlier study (Franczak, data unpublished) 20 IU OT were administered to cyclic gilts on days 15 to 18 of the oestrous cycle and resulted in a significant increase of plasma PGFM concentration. In this study plasma PGFM concentrations in OVX and steroidprimed gilts, were distinctly lower compared to the data of cyclic sows [10, 20,36]. We ovariectomized peripubertal six to seven-month old gilts. Thus, our results suggest that high doses of ovarian steroids in peripubertal gilts are insufficient for $\mathrm{PGF}_{2 \alpha}$ secretion/synthesis as is the case during the physiological oestrous cycle. In an in vitro study by Uenoyama et al. [46], endometrial cells of prepubertal gilts did not secrete
$\mathrm{PGF}_{2 \alpha}$ in response to OT until arachidonic acid was given into the culture medium. In OVX non-treated ewes [27] and prepubertal heifers [14], OT also had no influence on $\mathrm{PGF}_{2 \alpha}$ secretion. Presumably, in prepubertal and OVX non-treated females, there is an insufficient expression of genes for enzymes of the $\mathrm{PGF}_{2 \alpha}$ synthesis pathway [38]. Whereas, Edgerton et al. [11] showed that in OVX multiparous sows, receiving $\mathrm{E}_{2}$ and $\mathrm{P}_{4}$ replacement, PGFM plasma concentrations increased significantly in response to exogenous OT. In these sows basic and OT-stimulated plasma PGFM levels were about ten-fold higher compared to the results in the gilts in this study. However, our results and those by Edgerton et al. [11] agree about the interaction of $E_{2}$ $+\mathrm{P}_{4}$ for $\mathrm{PGF}_{2 \alpha}$ synthesis/secretion and the negative correlation between plasma $\mathrm{P}_{4}$ and PGFM response to OT.

Despite the PGFM response to OT in seven of the twenty-five gilts studied, OTR was present in the uterine wall of all these females. The low OTR concentration in the uterus of OVX-corn oil treated gilts increased about three-times and ten-times in response to injections of $\mathrm{P}_{4}$ and $\mathrm{EB}$ alone, respectively. In gilts receiving $\mathrm{EB}+\mathrm{P}_{4}$ this increase was similar to that obtained in gilts treated with $\mathrm{P}_{4}$ alone. The results in cows [24] and ewes [41] showed that endometrial OTR concentrations were similar in animals treated with $\mathrm{P}_{4}$ and $\mathrm{E}_{2}$ alone as compared to those treated with $\mathrm{P}_{4}+\mathrm{E}_{2}$. Likewise, in gilts with different plasma $\mathrm{P}_{4}$ levels (Gr II vs. Gr III and Gr V vs. Gr VI), OTR concentrations were similar. Thus in OVX gilts, both EB and $\mathrm{P}_{4}$ stimulated OTR synthesis in the uterine tissues, but the effect of EB was much more evident. During the physiological oestrous cycle, the highest endometrial OTR concentrations in gilts were also in the periestrous period and the lowest were during $\mathrm{P}_{4}$ dominance (luteal phase) [33]. In OVX pubertal ewes [47] and cows [24], OTR concentrations in the uterine tissues were high immediately following ovariectomy and they decreased gradually 
thereafter. A low uterine OTR level was also noticed in prepubertal heifers [14] and OVX ewes three months following ovariectomy [41]. The results of this study and those in heifers [14] and ewes [41] suggest that basic OTR concentration in females is independent of the ovarian steroids. On the contrary, it was shown that adrenal steroids of OVX gilts are the precursors of estrogens. These estrogens may cause an increase in the synthesis of endometrial glycoproteins, i.e. the $30-\mathrm{kDa}$ glycoprotein [15]. It is possible that adrenal estrogens in OVX gilts may be involved in uterine OTR synthesis.

The effect of exogenous $\mathrm{E}_{2}$ or $\mathrm{P}_{4}$ was able to stimulate OTR synthesis in the uterine tissues, lasting several days. Estrogens may directly influence the on OTR gene; these steroids have a sensitive element on the OTR gene, causing the elongation of poly(A)-mRNA and stabilising the transcript $[1,2]$. Whereas in studies by Uenoyama et al. [46], in endometrial tissues pooled from prepubertal gilts, and the next incubated with $\mathrm{E}_{2}$ or $\mathrm{P}_{4}$ OTR level did not increase. However, forskolin and cAMP increased OTR markedly in these studies. It was supposed that the $24 \mathrm{~h}$-lasting activity of ovarian steroids used in this study, was insufficient for demonstrating the stimulatory effect of steroids shown in an actual experiment. In conclusion, the results of the present study and those of Uenoyama [46] suggest that $\mathrm{E}_{2}, \mathrm{P}_{4}$ and yet unknown factor(s) acting throughout cAMP, are stimulators of OTR synthesis.

The dissociation constants of OTR in this study (mean \pm SEM; $6.15 \pm 1.9 \mathrm{nM}$ ) differed among groups and were higher compared to those obtained from the endometrium $(2.32 \pm 0.5 \mathrm{nM})$ and myometrium $(2.07 \pm$ $0.1 \mathrm{nM}$ ) of cyclic gilts, investigated under the same experimental conditions (Franczak et al., 2001, data unpublished) and those of other authors $[33,50]$. These results show a lower affinity of the studied OTR. Ludwig et al. [29] suggest that the endometrial responsiveness to OT in cyclic gilts is controlled at several levels of receptor activa- tion, such as OTR population density, their affinity to OT and the subsequent stimulation of a second messenger pathway.

In the present experiment, OTR concentration was studied in a mix of endometrial and myometrial cells. The results of our unpublished study in gilts (Franczak et al., 2001) indicate a similar hormonal control of OTR levels in both uterine tissues. On the contrary to data in gilts, $\mathrm{E}_{2}$ mainly influenced post-receptor mechanisms in ewes, but had a weaker role in OTR synthesis [42]. In OVX cows, low $\mathrm{E}_{2}$ plasma concentrations stimulate whilst high $\mathrm{E}_{2}$ concentrations inhibit the synthesis of endometrial OTR [24]. The role of $\mathrm{P}_{4}$ in OTR regulation in gilts also seems to be different in comparison to the results from ruminants. Endometrial cells, being under the influence of $\mathrm{P}_{4}$ for 10 days in ewes [25] and for 12 days in cows [30], had no functional OTR. However, OTR activity was observed between days 12-16 in ewes [26, 27] and days $16-20$ in cows $[24,30]$, independently of plasma $\mathrm{P}_{4}$ concentrations. Our results suggest that uterine OTR in gilts becomes functional when plasma $\mathrm{P}_{4}$ starts to decline. The ability of $\mathrm{P}_{4}$ to bind directly with OTR to block their activity has been reported by Grazzini et al. [17] in rats and has been confirmed in heifers [4]. In conclusion, (1) in OVX peripubertal gilts treatment with $\mathrm{E}_{2}$ and $\mathrm{P}_{4}$ basic plasma PGFM concentrations were influenced and the plasma metabolite level was higher in animals receiving $\mathrm{E}_{2}+\mathrm{P}_{4}$; (2) the response of PGFM on exogenous OT was weak in these gilts; (3) the uterine tissue of OVX gilts possessed OTR; (4) $\mathrm{P}_{4}$ and $\mathrm{E}_{2}$ applied separately stimulated uterine OTR concentrations in OVX gilts, but the effect of $E_{2}$ was more evident; and (5) the $K_{d}$ of OTR differed among groups studied.

\section{ACKNOWLEDGMENTS}

This study was supported by grant 02040.206 (University of Warmia and Mazury in Olsztyn). The authors are indebted to Dr. W.J. Silvia 
(University of Kentucky, Lexington, USA) for providing PGFM antiserum, to Mrs Bogumiła Mikołajczyk and Mrs Janina Bukowska for their technical assistance during these studies and to Dr Mamadou Moussa Bah (Institute of Reproduction and Food Research of the Polish Academy of Science, Olsztyn, Poland) for his help in editing the abstract in French and to $\mathrm{Mr}$ Jeffrey Taylor for linguistic revision of the paper.

\section{REFERENCES}

[1] Bale T.L., Dorsa D.M., Cloning, novel promoter sequence, and estrogens regulation of a rat oxytocin receptor gene, Endocrinology 138 (1997) 1151-1158.

[2] Bale T.L., Pedersen C.A., Dorsa D.M., CNS oxytocin receptor mRNA expression and regulation by gonadal steroids, Adv. Exp. Med. Biol. 395 (1995) 269-280.

[3] Beard A.P., Hunter M.G., Effects of progesterone pre-treatment on the oxytocin receptor concentration and the response to oxytocin during the stimulated early luteal phase in the ovariectomized ewe, J. Reprod. Fertil. 102 (1994) 57-63

[4] Bogacki M., Silvia W.J., Rekawiecki R., Młynarczuk J., Kotwica J., Inhibition of oxytocin binding and oxytocin stimulated prostaglandin $\mathrm{F}_{2} \alpha$ secretion by progesterone in bovine endometrium, International Conference on the Female Reproduction Tract, 26-29 May, 2000, Frauenchiemsee, Germany.

[5] Britt J.H., Esbenshade K.L., Zieçik A.J., Role of estradiol and gonadotropin-realising hormone in controlling negative and positive feedback associated with the luteinizing hormone surge in ovariectomized pigs, Biol. Reprod. 45 (1991) 478-485.

[6] Carnahan K.G., Prince B.C., Mirando M.A., Oxytocin stimulates uterine secretion of prostaglandin $\mathrm{F}_{2} \alpha$ in cyclic and early pregnant swine, Biol. Reprod. 55 (1996) 838-843.

[7] Charpigny G., Reinaud P., Tamby J.-P., Crémonon Ch., Martal J., MacLouf J., Guillomot M., Expression of cyclooxygenase- 1 and -2 in ovine endometrium during the oestrus cycle and early pregnancy, Endocrinology 138 (1997) 2163-2171.

[8] Dubois D.H., Smith L.C., Bazer F.W., Determination of porcine endometrial phospholipase $\mathrm{A}_{2}$ activity and detection of immunoreactive cyclooxygenase during the oestrous cycle and early pregnancy, Reprod. Fertil. Dev. 5 (1993) 531-543.

[9] Dziadkowiec I., Danilczyk H., Rembiesa R., Biosynthesis of progesterone in the placenta of rats (in Polish), Endocrinol. Pol. 33 (1982) 4-6.
[10] Edgerton L.A., Kamiński M.A., Silvia W.J. Changes in uterine secretion of prostaglandin $\mathrm{F}_{2}$ in response to oxytocin during the oestrus cycle, early pregnancy, and estrogens - induced pseudopregnancy in swine, Biol. Reprod. 55 (1996) 657-662.

[11] Edgerton L.A., Kamiński M.A., Silvia W.J., Effects of progesterone and estradiol on uterine secretion of prostaglandin $\mathrm{F}_{2}$ in response to oxytocin in ovariectomized sows, Biol. Reprod. 62 (2000) 365-369.

[12] Flint A.P.F., Leat E.L., Sheldrick E.J., Stewart H.J., Stimulation of phosphoinositide hydrolysis by oxytocin and the mechanism by which oxytocin controls prostaglandin synthesis in the ovine endomentrium, Biochem. J. 247 (1986) 798-805.

[13] Fuchs A.R., Behrens O., Helmer H., Lui C.H., Barros C.M., Fields M.J., Oxytocin and vasopressin receptors in bovine endometrium and myometrium during the oestrus cycle and early pregnancy, Endocrinology 127 (1990) 629-636.

[14] Fuchs A.R., Drolet P., Fortier A., Balvers M., Fields M.J., Ontogeny of oxytocin receptors and oxytocin-induced stimulation of prostaglandin synthesis in prepubertal heifers, Endocrinology 139 (1998) 2755-2764.

[15] Geisert R.D., Dixon M.J., Pratt T., Schmitt R.A.M., Lessley B.A., McCann J.P., Isolation and characterization of a $30-\mathrm{kDa}$ endometrial glycoprotein synthesized during the oestrus cycle and early pregnancy of the pig, Biol. Reprod. 53 (1995) 1038-1050.

[16] Gilbert C.L., Goode J.A., McGrath T.J., Pulsatile secretion of oxytocin during parturition in the pigs: temporal relationship with fetal expulsion, J. Physiol. 475 (1994) 129-137.

[17] Grazzini E., Guillon G., Mouilac B., Zingg H.H., Inhibition of oxytocin receptor function by direct binding of progesterone, Nature 392 (1998) 509-512.

[18] Homanics G.E., Silvia W.J., Effects of progesterone and estradiol $17 \beta$ on uterine secretion of prostaglandin $\mathrm{F}_{2 \alpha}$ in response to oxytocin in ovariectomized ewes, Biol. Reprod. 38 (1988) 804-811.

[19] Hotchikiss J., Atkinson L.E., Knobil E., Time course of serum estrogens and luteinizing hormone $(\mathrm{LH})$ concentrations during the menstrual cycle of the rhesus monkey, Endocrinology 89 (1971) 177-183.

[20] Kieborz K.R., Silvia W.J., Edgerton L.A., Changes in uterine secretion of prostaglandin $\mathrm{F}_{2 \alpha}$ and luteal secretion of progesterone in response to oxytocin during the porcine oestrus cycle, Biol. Reprod. 45 (1991) 950-954.

[21] Kotwica G., Franczak A., Okrasa S., Kotwica J., Effect of an oxytocin antagonist on prostaglandin $\mathrm{F}_{2 \alpha}$ secretion and the course of luteolysis in sows, Acta Vet. Hung. 47 (1999) 249-262. 
[22] Kotwica G., Sobczak J., Koziorowski M. Effects of opioid peptides, indomethacin and age on oxytocin and prolactin release during mating in sows, Reprod. Domest. Anim. 30 (1995) 257-263.

[23] Kotwica J., Krzymowski T., Debek J., Cannulation of veins in pig for endocrines studies (in Polish), Med. Wet. 2 (1978) 118-120.

[24] Lamming G.E., Mann G.E., Control of endometrial oxytocin receptors and prostaglandin $\mathrm{F}_{20}$ production in cows by progesterone and oestradiol, J. Reprod. Fertil. 103 (1995) 69-73.

[25] Lau T.M., Gow C.B., Fairclough R.J., Increases in the oxytocin induced prostaglandin $\mathrm{F}_{2}$ response and reduction in the concentrations of endometrial oxytocin receptors in ewes in response to progesterone, J. Reprod. Fertil. 95 (1992) 11-18

[26] Lau T.M., Kerton D.J., Gow C.B., Fairclough R.J., Role of progesterone in the control of endometrial oxytocin receptors at luteolysis in sheep, J. Reprod. Fertil. 98 (1993) 229-233.

[27] Lau T.M., Kerton D.J., Gow C.B., Fairclough R.J., Prolonged progesterone treatment increases the concentration of uterine oxytocin receptors in ovariectomized ewes, Anim. Reprod. Sci. 32 (1993) 205-212.

[28] Leung S.T., Wathes D.C., Regulatory effect of steroid hormones and fetal tissues on expression of oxytocin receptor in the endometrium of late pregnant ewes, J. Reprod. Fertil. 115 (1999) 243-250.

[29] Ludwig T.E., Sun B.-C., Carnahan K.G., Uzumcu M., Yelich J.V., Geisert R.D., Mirando M.A., Endometrial responsiveness to oxytocin during diestrus and early pregnancy in pigs is not controlled solely by changes in oxytocin receptor population density, Biol. Reprod. 58 (1998) 769-777.

[30] Mann G.E., Lamming G.E., Progesterone inhibition of the development of the luteolytic signal in cows, J. Reprod. Fertil. 104 (1995) 1-5.

[31] Mann G.E., Lamming G.E., Effect of the level of estradiol on oxytocin - induced prostaglandin $\mathrm{F}_{2}$ release in the cow, J. Endocrinol. 145 (1995) $175-180$.

[32] Mirando M.A., Becker W.C., Whiteaker S.S., Relationships among endometrial oxytocin receptors, oxytocin-stimulated phosphoinositide hydrolysis and prostaglandin $\mathrm{F}_{2 \alpha}$ secretion in vitro, and plasma concentrations of ovarian steroids before and during corpus luteum regression in cyclic heifers, Biol. Reprod. 48 (1993) 874-882.

[33] Okano A., Okuda K., Takahashi M., Schams D., Oxytocin receptors in the porcine endometrium during the estrous cycle and early pregnancy, Anim. Reprod. Sci. 41 (1996) 61-70.
[34] Okrasa S, Kotwica G., Ciereszko R., Dusza L., Czarnyszewicz J., Hormonal changes during lactation in sows: influence of spontaneous suckling on prolactin, oxytocin and corticoids concentrations, Exp. Clin. Endocrinol. 93 (1989) 95-103.

[35] Ottobre J.S., Houmard B.S., Ottobre A.C., Luteal production of steroids and prostaglandins during stimulated early pregnancy in the primate: differential regulation of steroids production by chorionic gonadotropin, Biol. Reprod. 41 (1989) 393-400.

[36] Printz V.J., Silvia W.J., Edgerton A., Changes in peripheral concentrations of 13,14-dihydro-15keto-prostaglandin $\mathrm{F}_{2}$ induced by progesterone in swine, J. Anim. Sci. 72 (1994) 459-463.

[37] Riley P.R., Flint A.P.F., Abayasekara D.R.E., Stewart H.J., Structure and expression of an ovine endometrial oxytocin receptor cDNA J. Mol. Endocrinol. 15 (1995) 195-202.

[38] Salamonsen L.A., Hampton A.L., Clements J.A. Findlay J.K., Regulation of gene expression and cellular localization of prostaglandin synthase by estrogen and progesterone in the ovine uterus, J. Reprod. Fertil. 92 (1991) 393-406.

[39] Sambrook J., Fritsch E.F., Maniatis T., Molecular cloning: a laboratory manual, Cold Spring Harbor Lab. Publ., New York, 1989.

[40] Schams D., Prokopp S., Oxytocin determination by RIA in cows around parturition, Anim. Reprod. Sci. 2 (1979) 267-270.

[41] Sheldrick E.L., Flint A.P.F., Endocrine control of uterine oxytocin receptors in the ewe, J. Endocrinol. 106 (1985) 249-258.

[42] Sheldrick E.L., Flick-Smith H.C., Effect of ovarian hormones on oxytocin receptor concentrations in explants of uterus from ovariectomized ewes, J. Reprod. Fertil. 97 (1993) 241-245.

[43] Silvia W.J., Lewis G.S., McCracken J.A., Thatcher W.W., Wilson L., Hormonal regulation of uterine secretion of prostaglandin $\mathrm{F}_{2}$ during luteolysis, Biol. Reprod. 45 (1991) 655-663.

[44] Stewart H.J., Stevenson K.R., Flint A.P.F., Isolation and structure of a partial sheep oxytocin receptor cDNA and its use as a probe for Northern analysis of endometrial RNA, J. Mol. Endocrinol. 10 (1993) 359-361.

[45] Szafrańska B., Tilton J.E., Prolactin as a luteoltrophin during late pregnancy in pigs, $\mathrm{J}$. Reprod. Fertil. 98 (1993) 643-648.

[46] Uenoyama Y., Hattori S.-I., Miyake M., Okuda $\mathrm{K}$., Up-regulation of oxytocin receptors in porcine endometrium by adenosine $3,5^{\prime}$ monophosphate, Biol. Reprod. 57 (1997) 723-728.

[47] Vallet J.L., Lamming G.E., Batten M., Control of endometrial oxytocin receptor and uterine response to oxytocin by progesterone and oestradiol in the ewe, J. Reprod. Fertil. 90 (1990) 625-634. 
[48] Wathes D.C., Hamon M., Localization of oestradiol, progesterone and oxytocin receptors in the uterus during the oestrous cycle and early pregnancy of the ewe, J. Endocrinol. 138 (1993) 479-491.

[49] Wathes D.C., Mann G.E., Payne J.H., Riley P.R., Stevenson K.R., Lamming G.E., Regulation of oxytocin, oestradiol and progesterone receptor concentrations in different uterine regions by oestradiol, progesterone and oxytocin in ovariectomized ewes, J. Endocrinol. 151 (1996) 375-393.
[50] Whiteaker S.S., Mirando M.A., Becker W.C., Hostetler C.E., Detection of functional oxytocin receptors on endometrium of pigs, Biol. Reprod. 51 (1994) 92-98.

[51] Whiteaker S.S., Mirando M.A., Becker W.C., Peters D.N., Relationship between phosphoinositide hydrolysis and prostaglandin $\mathrm{F}_{2 \alpha}$ secretion in vitro from endometrium of cyclic pigs on day 15 postestrus, Dom. Anim. Endocrinol. 12 (1995) 95-104.

[52] Ziẹcik A., Doboszyńska T., Dusza L., Concentrations of $\mathrm{LH}$, prolactin and progesterone in early-pregnant and oestradiol-treated gilts, J. Anim. Sci. 10 (1986) 215-224. 